\title{
Ten-year experience of allogeneic haploi- dentical hematopoietic stem cell trans- plantation with non-manipulated grafts in children and adolescents with high-risk acute leukemia
}

Olesya V. Paina, Polina V. Kozhokar, Anastasia S. Borovkova, Anastasia S. Frolova, Kirill A. Ekushov, Tatyana A. Bykova, Zhemal Z. Rakhmanova, Mariya A. Galas, Aigul G. Khabirova, Inna V. Markova, Elena V. Semenova, Sergey N. Bondarenko, Elena V. Babenko, Tatyana L. Gindina, Alexander L. Alyanskiy, Ildar M. Barkhatov, Boris I. Smirnov, Ludmila S. Zubarovskaya, Boris V. Afanasyev

R. Gorbacheva Memorial Research Institute of Children Oncology, Hematology and Transplantology at the First St. Petersburg State I. Pavlov Medical University; St. Petersburg State Electrotechnical University «LETI», St. Petersburg, Russia

Dr. Olesya V. Paina, R. Gorbacheva Memorial Research Institute of Children Oncology, Hematology and Transplantology at the First St. Petersburg, State I. Pavlov Medical University L. Tolostoy St. 6-8, 197022, St. Petersburg, Russia

\section{Summary}

Haploidentical transplantation (Haplo-HSCT) is an effective method for treating patients with high-risk acute leukemias (AL) who do not have HLA-matched related (MRD) and matched unrelated donors (MUD). During 10 years in R/G/Memorial Institute of children oncology, hematology and transplantation more than 150 patients have Haplo-HSCT. More than $50 \%$ of patients were «salvage group» patients.

\section{Materials and methods}

106 patients with high-risk AL, median age 7 y.o. (range 0-18), acute lymphoblastic leukemia (ALL) 63 (59.4\%), acute myeloid leukemia (AML) - 43 (40.6\%), received Haplo-HSCT from December 2006 till December 2016. Forty three patients (40.6\%) recived Haplo-HSCT in complete remission (CR): CR1 21 patients (49\%), CR2 - 13 patients (30\%), CR3 - 9 patients (21\%). Resistance disease or resistance relapse AL - 63 (59.4\%) patients. Conditioning regimens were as follows: MAC «GIAC» 39 patients (36.8\%), MAC based on Busulfan 12mg/b.w. and Fludarabine $150 \mathrm{mg} / \mathrm{mg}(2)-$ 2 (2\%), MAC reduced toxisity based on Treosulfan $42 \mathrm{~g} / \mathrm{m}(2)-6(5.7 \%)$, RIC based on Melfalan 140 $\mathrm{mg} / \mathrm{m}(2)-40$ (37.7\%), RIC with Busulfan 8 mg/b.w. -
Phone: +7 (921) 747-04-32

E-mail:paina@mail.ru

18 (17\%). All patients received prophylaxis of acute graft versus host disease (aGVHD). Seroprophylaxis with ATG - ATGAM 60mg/b.w. - 39 (36.8\%), posttransplant cyclophosphomide $50 \mathrm{mg} / \mathrm{b} . \mathrm{w}$. on $\mathrm{D}+3, \mathrm{D}+4-$ $67(63.2 \%)$. Conventional immunosuppressive therapy: tacrolimus 47 patients (44.3\%), CsA 59 patients (55.7\%). Source of transplant - combined unmanipulated stimulated Haplo-bone marrow plus manipulated (positive selected CD34 ${ }^{+}$) stimulated $\mathrm{CD} 34^{+}$cells -27 patients $(25.5 \%)$ and unmanipulated stimulated Haplo-bone marrow - 79 (74.5\%). Stem cells dose of unmanipulated stimulated Haplo-bone marrow transplant CD $34^{+} \times 10^{6} /$ b.w. median 5.9x10(6)/b.w., stem cells dose of combined transplant median 5.9x10(6)/b.w. (range from 2.5 till 30.9x10(6)/b.w.

\section{Statistical analysis}

SPSS Statistics v.17. Overal survival (OS) was defined as time from study enrollment to death, with living patients censored on the date of the last follow-up. The KaplanMeier method was used to estimate OS rates, and the exact log-rank test was used to compare survival curves. Survival estimates are reported with standard errors determined by the method of Peto and Pike. 


\section{Conclusion}

Haplo-HSCT in 1 and 2 remissions of AL allows to achieve 10 -year OS in $64.7 \%$ of children, while the type of acute leukemia does not influence the outcome of haplo-HSCT. The acceptable frequency of development of aGVHD III ${ }^{0}-\mathrm{IV}^{0}-18.6 \%$ allows to treat haplo-HSCT as therapy in 1 and 2 remissions of high risk group. The main complication of haplo-HSCT is relapse $-23.5 \%$ in the early posttransplant period to $\mathrm{D}+100$.

\section{Keywords}

Allogeneic hematopoietic stem cell transplantation, haploidentical, children, overall survival, relapse, graftversus-host disease.

\section{Introduction}

Allogeneic hematopoietic stem cell transplantation (allo-HSCT) is an effective treatment option in a number of high-risk oncohematological patients [1]. Availability of HLA-identical siblings or compatible unrelated donors is a common limiting factor for broader allo-HSCT practice, especially among ethnical minorities $[2,3,4]$. Sufficient growth of allo HSCT worldwide activities occurs because of lowering limitations by the stage of diseases, patients' age and comorbidities, due to introduction of fludarabin-containing conditioning regimens (RICs), thus reducing intensity of cytostatic load and transplantation-associated mortality while retaining efficiency and of treatment, along with immunoadoptive effects $[5,6,7]$. Meanwhile, nearly all patients have a potential haploidentical family donor. However, early attempts of haplo-HSCT using a native graft without $\mathrm{T}$ cell purging using standard immunosuppression shedules resulted into unacceptable graft-versus-host disease (GVHD) rates whereas ex vivo $\mathrm{T}$ cell depletion for GVHD control was accomplished by high risk of non-engraftment and infectious complications causing high mortality $[8,9,10,11]$. In Russia, approximately $80 \%$ of patients requiring allo-HSCT do not have a compatible sibling donor, whereas a chance to find an unrelated donor do not exceed $60-70 \%$, requiring high financial costs, thus presenting the main obstacle for timely performance of allo-HSCT [3].

Search for alternative stem cell sources, such as umbilical blood cells, or haploidentical donor is quite challenging. To control HSCT risks and to prevent non-engraftment, the workers form Perugia (Italy) have used megadoses of CD34+ cells after their positive selection (a median of $>10 \times 10^{6}$ / $\mathrm{kg}$ weight), with minimal $\mathrm{T}$ cell contamination (a median of $1 \times 10^{4} / \mathrm{kg}$ weight) combined with intensive conditioning regimen [11]. This study reported engraftment in 94 of 101 patients with good GVHD control. However, the rates of non-relapse-associated mortality proved to be very high (36.5\%) which were largely determined by infections associated with slow immunological recovery. Event-free survival was satisfactory in the patients transplanted in remission, being, however, extremely poor for the patients treated in resistant or relapsing cases. Complexity of this transplantation approach and high costs of the method limited its approval by other transplantation centers.

A group of Chinese workers has used a method avoiding ex vivo $\mathrm{T}$ cell depletion based on intensive pre-transplant treatment using myeloablative GIAC conditioning regimens (MAC) combined with anti-thymocyte gobulin as in vivo $\mathrm{T}$ cell depletion. The research team used a combined non-manipulated graft containing stimulated peripheral HCSs and bone marrow HSCs. 250 patients with acute leukemias were reported to achieve full donor chimerism, whereas acute and chronic GVHD frequencies were, respectively, $46 \%$ and $54 \%$. Despite satisfactory relapse-free survival rates, the standard-risk patients often suffered with opportunistic infections, Transplant-related mortality rates for standard-risk and high-risk groups were, respectively, $19.5 \%$ и $29.5 \%$ for acute myeloid leukemia (AML), or $21 \%$ and $51 \%$ for acute lymphoblastic leukemia (ALL) [13]. Another approach to allo-HSCT was developed in Baltimore (USA) included usage of non-manipulated graft followed by post-transplant cyclophosphamide injection (PtCy) to control $\mathrm{T}$ cell reactivity after HSCT seems to overcome most obstacles historically connected with haplo-HSCT $[14,22]$.

Over last years, the haplo-HSCT methodology has experienced sufficient changes, i.e., novel conditioning protocols were developed with decreased toxicity and low dose intensity; the ex vivo $\mathrm{T}$ cell depletion options were designed, i.e., $\mathrm{CD} 34+$ cell selection, $\mathrm{CD}^{+} / \mathrm{CD} 19^{+}$cell depletion, $\gamma / \beta$ TCR chain depletion. The in vivo trials, suggest favorable effects from usage of anti-thymocyte globulins (ATG), cyclophosphamide at at high doses on D+3, D+4 after the haploidentical transplant. An immune response modification could be carried out as reduction of $\mathrm{T}$ cell reactivity by changing the Th1/Th2 balance, by means of hematopoiesis stimulation with G-CSF before myeloexfusion. Pharmacological prophylaxis of acute GVHD (aGVHD) is accomplished by new therapies, e.g., with rapamycin, the mTOR inhibitor [14, $15,16]$. Good efficiency of haploidentical HSCT is shown for the $1^{\text {st }}$ and $2^{\text {nd }}$ remissions of AML, with 5-year relapse-free survival of $82.5 \%$, and $59.4 \%$. Appropriate figures for ALL were $68.9 \%$ and $56.6 \%$ [15]. The results of relapsed and resistant clinical forms were unsatisfactory if using allo-HSCT, or hapolo-HSC, i.e., the 5-year overall survival in AML was $42.9 \%$ and $22.2 \%$ in ALL $[15,16,17,18]$. The aim of our study was to assess efficiency of haplo-HSCT performed with non-manipulated grafts of children and adolescents with high-risk acute leukemias. In this respect an efficiency study of haploidentical GVHD was performed at our clinic in children and adolescents with high-risk ALL and AML, at maximal observation terms of 10 years. 


\section{Patients and methods}

The study included 106 children and adolescents 0 to 18 years old (median age, 7 y.o.). with primary diagnosis of ALL in 63 cases (59.4\%), and AML (43 patients, 41\%), who underwent allo-HSCT from haploidentical donors within a time period of December 2006 to December 2016 года. The patients were followed up for a maximum of 10 years.

Haploidentical HSCT was performed in remission state for 43 patients $(40.6 \%)$, i.e., 21 patients were transplanted in $1^{\text {st }}$ remission, 13 patients, in $2^{\text {nd }}$ remission, and nine children were treated in $3^{\text {rd }}$ remission. Sixty-three relapsed/ therapy-resistant $(\mathrm{R} / \mathrm{R})$ patients with $\mathrm{AL}$ were transplanted (59.4\% of total). Several MAC schedules were applied for conditioning treatment, i.e., GIAC protocol (39 cases, $36.8 \%$ of total) including busulfan ( $16 \mathrm{mg} / \mathrm{kg}$ body weight), cyclophosphamide (Cy) at a dose of $2000 \mathrm{mg} / \mathrm{m}^{2}$, cytosar $(8000$ $\left.\mathrm{mg} / \mathrm{m}^{2}\right)$, lomustin $(120 \mathrm{mg} / \mathrm{kg})$. Other MACs were based on busulfan $(12 \mathrm{mg} / \mathrm{kg})$ and Fludarabin $\left(150 \mathrm{mg} / \mathrm{m}^{2}\right)$, being applied in 2 patients (2\%), and a regimen based on Treosulfan $\left(42 \mathrm{~g} / \mathrm{m}^{2}\right)$ was used in 6 cases $(5.7 \%)$. The reduced-intensity conditioning regimens (RICs) based on melphalan (140 mg/ $\mathrm{m}^{2}$ ) were applied in 40 recipients $(37.7 \%)$, whereas RICs containing busulfan $(8 \mathrm{mg} / \mathrm{kg})$ were used in 18 patients $(17 \%)$.
All the patients underwent aGHVD prophylaxis, i.e., antithymocyte globulin (ATGAM) was injected at $60 \mathrm{mg} / \mathrm{kg}$ weight in 39 cases $(36.8 \%)$; whereas post-transplant cyclophosphamide (PtCy, $50 \mathrm{mg} / \mathrm{kg}$ ) was injected on D+3 and D+4 in 67 recipients (63.2\%). Basic immune suppressive therapy (IST) included Tacrolimus $(0.03 \mathrm{mg} / \mathrm{kg} / \mathrm{d})$ for 47 patients $(44.3 \%)$; cyclosporine A (3 mg/kg/d was used in 59 cases $(55.7 \%)$. In addition to tacrolimus, an mTOR inhibitor at $1 \mathrm{mg} / \mathrm{m}^{2}$ was administered since $\mathrm{D}+3$. Clinical parameters of the patients enrolled into the study, are summarized in Table 1.

Two methods were used for yielding the haploidentical donor grafts, i.e.:

1. A combined graft containing bone marrow and peripheral hematopoietic stem cells (PHSCs) obtained after G-CSF priming ( $5 \mathrm{mg} / \mathrm{kg} / \mathrm{d}$, for 4 days) then followed by positive selection of CD34+ клеток with a CliniMACS device (Miltenyi Biotec). This cell product was applied in 27 cases (25.5\%).

2. Non-manipulated marrow graft primed with G-CSF ( $5 \mathrm{mg} / \mathrm{kg} / \mathrm{d}$ for 3 days) was obtained and used in 79 patients (74.5\%). The median cellularity as for transfused CD34+ cells comprised $5.9 \times 10^{6} / \mathrm{kg}$ weight for non-manipulated bone marrow $\left(1.0\right.$ to $\left.9 \times 10^{6} / \mathrm{kg}\right)$, and $5.9 \times 10^{6} / \mathrm{kg}$ for the combined graft $\left(2.5\right.$ to $\left.30.9 \times 10^{6} / \mathrm{kg}\right)$.

Table 1. Characteristics of the patients subjected to haploidentical HSCT

\begin{tabular}{|c|c|}
\hline Parameters & Number of patients (a total of 106 cases) \\
\hline Median age, years & $7(0-18)$ \\
\hline $\begin{array}{l}\text { Sex ratio } \\
\text { M:F }\end{array}$ & $65: 41$ \\
\hline $\begin{array}{l}\text { Primary diagnosis } \\
\text { Acute lymphoblastic leukemia } \\
\text { Acute myeloblastic leukemia }\end{array}$ & $\begin{array}{l}63(59.4 \%) \\
43(40.6 \%)\end{array}$ \\
\hline Maximal follow-up terms & 10 years \\
\hline $\begin{array}{l}\text { Clinical status at the time of HSCT } \\
\text { Remission state } \\
1^{\text {st }} \text { remission } \\
2^{\text {nd }} \text { remission } \\
3^{\text {rd }} \text { remission } \\
\text { Treatment-resistant disease, or resistant relapse }\end{array}$ & $\begin{array}{l}43(40.6 \%) \\
21(49 \%) \\
13(30 \%) \\
9(21 \%) \\
63(59.4 \%) \\
\end{array}$ \\
\hline Donor/recipient HLA compatibility (5/10) & $106(100 \%)$ \\
\hline \multicolumn{2}{|l|}{ Conditioning regimen } \\
\hline $\begin{array}{l}\text { MAC «GIAC» } \\
\text { MAC (Busulfan } 12 \mathrm{mg} / \mathrm{kg} \text { ) } \\
\text { MAC (Treosulfan } 42 \mathrm{~g} / \mathrm{m}^{2} \text { ) } \\
\text { RIC (Melphalan } 140 \mathrm{mg} / \mathrm{m}^{2} \text { ) } \\
\text { RIC (Busulfan } 8 \mathrm{mg} / \mathrm{kg} \text { ) } \\
\end{array}$ & $\begin{array}{l}39(36.8 \%) \\
2(2 \%) \\
6(5.7 \%) \\
40(37.7 \%) \\
18(17 \%)\end{array}$ \\
\hline \multicolumn{2}{|l|}{ Acute GVHD prophylaxis } \\
\hline $\begin{array}{l}\text { Seroprophylaxis with ATGAM } \\
\text { Posttransplant Cyclophosphamide D+3, D+4 }\end{array}$ & $\begin{array}{l}39(36.8 \%) \\
67(63.2 \%)\end{array}$ \\
\hline \multicolumn{2}{|l|}{ Basic GVHD prophylaxis } \\
\hline $\begin{array}{l}\text { Cyclosporin A } \\
\text { Tacrolimus + Sirolimus }\end{array}$ & $\begin{array}{l}59(55.7 \%) \\
47(44.3 \%)\end{array}$ \\
\hline
\end{tabular}


For statistical evaluation, SPSS Statistics v.17 and Statistica 8.0 software was used. The patients in remission are censored for 01.01.2018. Overall survival was compared by means of log-rank test, comparative analysis of differential proportions was performed by the Fisher's exact test. The difference levels of $\mathrm{p}<0.05$ were considered significant.

\section{Results}

\section{Hematopoiesis recovery}

Stem cell engraftment after haplo-HSCT was documented in 80 total group of patients $(75.7 \%$ of total). Median engraftment term was D+24 (D+14 to D+34). Primary non-engraftment was revealed in 26 patients $(24.5 \%)$ due to chemoresistance and/or relapsed AL. The median recovery terms for granulocytes $\left(>0.5 \times 10^{9} / \mathrm{L}\right)$ was $\mathrm{D}+19(\mathrm{D}+10$ to $\mathrm{D}+34)$; for leukocytes $\left(>1.0 \times 10^{9} / \mathrm{L}\right), \mathrm{D}+17(\mathrm{D}+10$ to $\mathrm{D}+34)$; for platelets reconstitution $\left(>20 \times 10^{9} / \mathrm{L}\right), \mathrm{D}+17(\mathrm{D}+10-\mathrm{D}+41)$. Median recovery time for lymphocytes $\left(>30 \times 10^{9} / \mathrm{L}\right)$ was $\mathrm{D}+29$ $(\mathrm{D}+14$ to $\mathrm{D}+50)$. Full donor chimerism was registered in 67 cases $(83.8 \%)$ by day +30 posttransplant. Thirteen patients (16.2\%) developed full chimerism by day +60 after HSCT.

\section{Survival data}

Ten-year overall survival (OS) in total group proved to be $33.3 \%$ after haplo-HSCT (Fig. 1). In particular, the ten-year OS in patients transplanted in $1^{\text {st }}$ and $2^{\text {nd }}$ remissions was $64.7 \%$ as compared to $18.1 \%$ for the patients transplanted beyond the remission. ( $p=0.01$; Fig. 2 ). Overall survival for the patients who received G-CSF-primed, non-manipulated bone marrow and in those who got combined marrow/peripheral grafts was, respectively, $38 \%$ and $18.5 \%$ ( $\mathrm{p}=0.03$, Fig. 3 ). The AL type did not influence the 10 -year survival, i.e.,

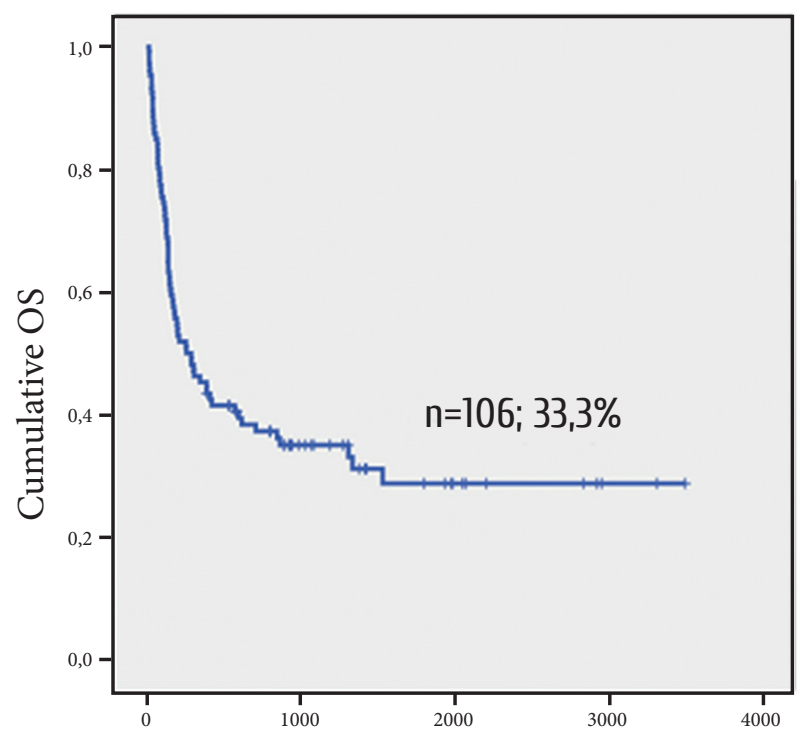

10 y. after Haplo-HSCT

Figure 1. Ten-year overall survival in children and adolescents with acute leukemias after haplo-HSCT
$36.5 \%$ vs $27.9 \%$ respectively, for ALL and AML subgroups. The OS values in ALL versus AML patients transplanted in $1^{\text {st }}$ or $2^{\text {nd }}$ remissions have shown comparable OS rates, respectively, $68.2 \%$ and $58.3 \%$. We could not show any significant correlations between the 10-year survival and recovery kinetics of leukocytes, neutrophils and platelets post-transplant.

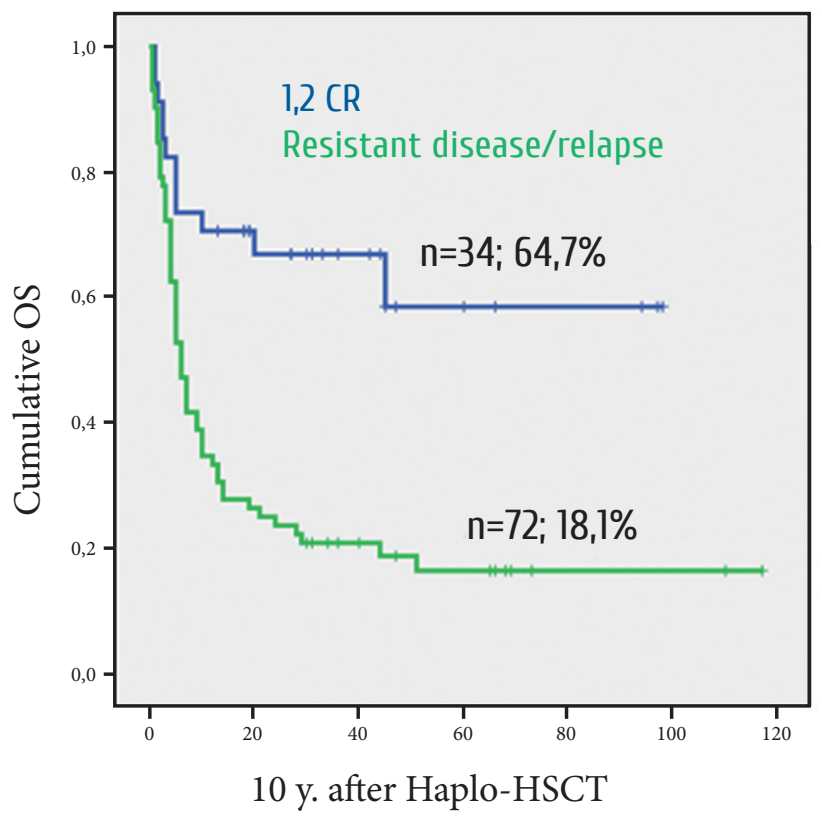

Figure 2. Ten-year overall survival in children and adolescents after haplo-HSCT performed in $1^{\text {st }}$ and $2^{\text {nd }}$ remission $(p=0.01)$

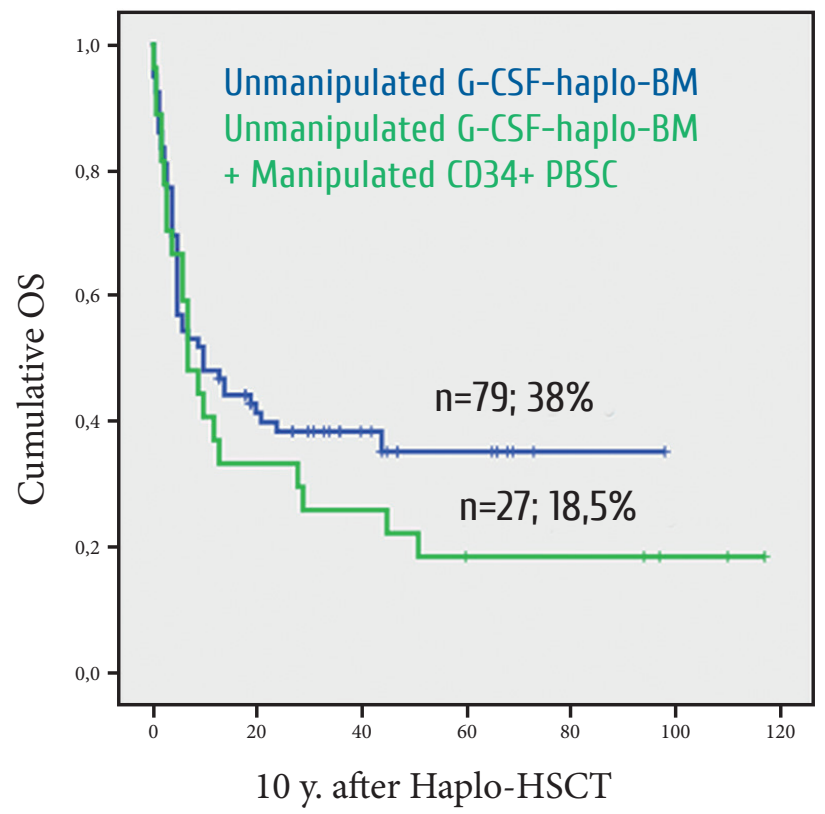

Figure 3. Ten-year overall survival in children and adolescents after haplo-HSCT for the groups receiving a G-CSF-primed nonmanipulated bone marrow (blue graph), or a combined hematopoietic graft (green graph). The difference is significant at $\mathrm{p}=0.03$ 
Table 2. Comparative indexes of the 10-year overall survival and recovery of granulocytes, platelets and lymphocytes

\begin{tabular}{|l|l|l|}
\hline Factor & Value, \% & P values \\
\hline Overall survival in the group & 33.3 & \\
\hline Cranulocytes (>0.5x10 $/ L)$ & & \\
$D+21$ & $33 \%$ & $>0.05$ \\
$>D+21$ & $39.5 \%$ & \\
Platelets $\left(>20 \times 10^{9} / \mathrm{L}\right)$ & & \\
$D+20$ & $43.9 \%$ & $>0.05$ \\
$>D+20$ & $35.7 \%$ & \\
Lymphocytes $\left(>30 \times 10^{9} / L\right)$ & & \\
$D+30$ & $39 \%$ & $>0.05$ \\
$>D+30$ & $40 \%$ & \\
\hline
\end{tabular}

Comparative OS values are presented in Table 2. The 10-year OS did not statistically differ between the groups receiving different conditioning regimens. It could be explained by small numbers of cases and inability to tolerate the full-dose conditioning regimens in resistant $\mathrm{AL}$ cases. Hence, $\mathrm{OS}$ rates among patients who received MAC regimens comprised $36.2 \%$ as compared to $30.5 \%$ for the RIC group. The OS values upon more detailed evaluation and subgroup division were as follows: MAC, 28.6\%; MAC+PtCy treatment, 40\%; RIC, 16.7\%, and RIC+PtCy, 38.1\% ( $\mathrm{p}>0.05)$.

\section{Posttransplant complications}

Acute graft-versus-host disease (GVHD) is a major immunological disorder developing early after allo-HSCT. Of 80 patients who achieved engraftment, aGVHD grade II was observed in 21 cases (26.3\%); severe GVHD (grade III to IV) was diagnosed in 15 patients (18.6\%).

Leukemia relapses were registered in 51 of 106 patients (48.1\%), with a mediane of D+91 after haplo-HSCT (D+17 to $\mathrm{D}+1101)$. Occurrence of relapses post haplo-HSCT, if performed in $1^{\text {st }}$ or $2^{\text {nd }}$ remission was $23.5 \%$, with a median of $\mathrm{D}+88(\mathrm{D}+30$ to $\mathrm{D}+301)$. The disease recurrence was more common in recipients with resistant or relapsing disease $(56,9 \%$, with a median development on $\mathrm{D}+81$ post-transplant).

The overall transplant-associated mortality was $21.6 \%$ in the studied group. Fatal infectious complications in the early post-transplant period were registered in 14 patients $(13.2 \%)$. Acute GVHD caused death of 7 patients $(8.8 \%)$, lethal toxic conditions, in 2 cases (1.9\%). Meanwhile, the leukemia relapses proved to prevail in post-engraftment lethality among children and adolescents undergoing haplo-HSCT (39 patients, 48.8\%). Posttransplant relapses among the patients transplanted in $1^{\text {st }}$ and $2^{\text {nd }}$ remissions resulted into lethal outcome in 6 cases (17.6\%). Meanwhile, the AL recurrence with lethal outcome was registered in 33 cases (45.8\%) among patients who received haploidentical grafts in resistant or relapsing disease upon engraftment.

\section{Discussion}

At the present time, HSCT from haploidentical donors is known to be an effective and safe treatment approach for the high-risk leukemia patients, requiring allo-HSCT for urgent reasons, especially in absence of a compatible donors, either related or unrelated ones. Fast preparation of a donor and HSC isolation, good chances for repeated graft harvest if required, as well as minimal financial costs comprise clear benefits of haplo-HSCT. However, some cautions exist, due to risks of posttransplant complications, such as acute GVHD and severe infections determined by marked immunosuppression and prolonged immune recovery after haplo-HSCT. Moreover, a specific graft-versus-leukemia $(\mathrm{GvL})$ response after haplo-HSCT and persistence of this effect is still in question, being subject to different studies [20]. Application of RIC regimens as a platform for the post-transplant immunonadoptive therapy may provide an additional tool for enhancement of the GvL immune reaction without increasing the transplant-related mortality.

Some promising data on the subject are published by a study team at the John Hopkins and Fred Hutchinson Cancer Research Center on the patients with high-risk acute leukemia who underwent reduced-intensity conditioning followed by haplo-HSCT and post-transplant cyclophosphamide injections on $\mathrm{D}+3$ and $\mathrm{D}+4$. According to this study, clinical engraftment was registered in $87 \%$ of the cases, with OS values of $41 \%$. Clinically sound aGHVD (grade II-IV) was registered in $<27 \%$, with chronic GVHD documented in $15 \%$ of the cases. However, frequency of post-transplant relapses remained high $(55 \%)$, with relatively low transplant-related mortality (18\%) [20, 22].

Our own data on haplo-HSCT confirm the high rates of transplant engraftment (80\%), while reaching full donor chimerism by day +30 in $84 \%$ of the cases. The rest of this group developed full chimerism by day +60 post-HSCT. Overall survival with a maximal observation term of 10 years was $33.3 \%$ for the total group. Frequency of clinical aGVHD in our study is also comparable to the previously reported data, 
i.e., prevalence of aGVHD grade II was $26.3 \%$, aGVHD grade III-IV, $18.6 \%$, which does not exceed the published values [20]. We have obtained encouraging results on the 10 -year overall survival $(64.7 \%)$ for the haplo-HSCT patients who received their graft during $1^{\text {st }}$ and $2^{\text {nd }}$ remissions. Absence of severe lethal infectious complications before $\mathrm{D}+100$ seems to be connected with faster $\mathrm{T}$ cell reconstitution.

Post-transplant relapses represent the main problem for these patients. High percentage of such dismal outcomes (48.1\%) may be explained by the disease status at the time of haplo-HSCT. The majority of patients (72 cases, $68 \%$ ) were transplanted beyond the registered remission. According to the data published by Italian workers, the relapse rates may reach $50 \%$ in such patient groups $[7,12]$.

\section{Conclusion}

Allo-HSCT of the non-manipulated primed bone marrow from a haploidentical donor proved to be an effective approach, in order to achieve clinical remission in children and adolescents with high-risk AL. At the present time, one may discuss relative benefits of different stem cell separation techniques for haplo-HSCT in childhood. Implementation of post-transplant cyclophosphamide (PtCy) proved to be an available and effective regimen improving clinical results of haplo-HSCT. State of the disease is the main factor influencing overall survival after haplo-HSCT. First or second remission of ALL or AML is the optimal time-point for haplo-HSCT. To improve the results of haplo-HSCT in Russia, the appropriate cooperative multicentric studies are required in this research area.

\section{Conflict of interest}

The authors report no conflicts of interest.

\section{References}

1. Lucchini G, Labopin M, Beohou E, Dalissier A, Dalle JH, Cornish J, Zecca M, Afanasyev B et al. Impact of conditioning regimen on outcomes for children with acute myeloid leukemia undergoing transplantation in first complete remission. An analysis on behalf of the Pediatric Disease Working Party of the European Group for Blood and Marrow Transplantation. Biol Blood Marrow Transplant. 2017; 23(3):467-474.

2. Bashey A, Solomon SR. T-cell replete haploidentical donor transplantation using post-transplant CY: an emerging standard-of-care option for patients who lack an HLA-identical sibling donor. Bone Marrow Transplantation 2014; 49, 999-1008.

3. Alyanskyi AL, Kucher MA, Makarenko OA, Golovacheva AA, Kuzmich EV, Babenko EV, Estrina MA, Paina OV, Pevtcov DE, Zubarovskaya LS, Afanasyev BV. Actual issues of search for unrelated bone marrow donors in Russian Federation. Transfuziologiya. 2016; 3:21-28 (In Russian).

4. Santoro N, Ruggeri A, Labopin M, Bacigalupo A, Ciceri F, Gulbas Z, Huang H, Afanasyev B et al. Unmanipulated haploidentical stem cell transplantation in adults with acute lymphoblastic leukemia: a study on behalf of the Acute Leukemia Working Party of the EBMT. J Hematol Oncol. 2017; 10 (1): 113.

5. Semenova EV, Stancheva NV, Alyanskyi AL, Babenko EV, Vavilov VN, Morosova EV, Bondarenko SN, Sipol AA, Paina OV, Barkhatov IM, Zubarovskaya LS, Afanasyev BV. Alogeneic hematopoietic stem cell transplantation with reduced-intensity conditioning in children and adolescents with prognostically infavorable forms of acute lymphoblastic leukemia. Onkogematologiya. 2011; 4:25-32 (In Russian).

6. Bitan M, He W, Zhang M-J, Abdel-Azim H, Ayas MF, Bielorai B, Carpenter PA et al. Transplantation for children with acute myeloid leukemia: a comparison of outcomes with reduced intensity and myeloablative regimens. Blood 2014; 123(10): 1615-1620.

7. Solomon SR, Sizemore CA, SanacoreM, et al. Haploidentical transplantation using $\mathrm{T}$ cell replete peripheral blood stem cells and myeloablative conditioning in patients with high-risk hematological malignancies who lack conventional donors is well tolerated and produces excellent relapse-free survival: results of a prospective phase II trial. Biol Blood Marrow Transplant. 2012;18:1859-1866.

8. Anasetti C, Beatty PG, Storb R, Martin PJ, Mori M, Sanders JE et al. Effect of HLA incompatibility on graft-versus-host disease, relapse, and survival after marrow transplantation for patients with leukemia or lymphoma. Hum Immunol 1990; 29: 79-91.

9. Beatty PG, Clift RA, Mickelson EM, Nisperos BB, Flournoy N, Martin PJ et al. Marrow transplantation from related donors other than HLA-identical siblings. N Engl J Med. 1985; 313:765-771.

10. Powles RL, Morgenstern GR, Kay HE, McElwain TJ, Clink HM, Dady PJ et al. Mismatched family donors for bone-marrow transplantation as treatment for acute leukaemia. Lancet 1983; 1:612-615.

11. Szydlo R, Goldman JM, Klein JP, Gale RP, Ash RC, Bach $\mathrm{FH}$ et al. Results of allogeneic bone marrow transplants for leukemia using donors other than HLA-identical siblings. J Clin Oncol. 1997; 15:1767-1777.

12. Aversa F, Terenzi A, Tabilio A, Falzetti F, Carotti A, Ballanti $S$ et al. Full haplotype mismatched hematopoietic stem-cell transplantation: a phase II study in patients with acute leukemia at high risk of relapse. J Clin Oncol. 2005; 23:3447-3454.

13. Huang XJ, Liu DH, Liu KY, Xu LP, Chen H, Han W et al. Treatment of acute leukemia with unmanipulated HLA-mismatched/haploidentical blood and bone marrow transplantation. Biol Blood Marrow Transplant. 2009; 15:257-265.

14. Berenbaum MC, Brown IN. Prolongation of homograft survival in mice with single doses of cyclophosphamide. Nature $1963 ; 200: 84$

15. Kekre N, Antin JH. Hematopoietic stem cell transplantation donor sources in the 21st century: choosing the ideal donor when a perfect match does not exist. Blood 2014; 123 (3):334-343. 
16. Moiseev IS, Pirogova OV, Alyanski AL, Babenko EV, Gindina TL, Darskaya EI, Slesarchuk OA, Bondarenko SN, Afanasyev BV. Graft-versus-Host disease prophylaxis in unrelated peripheral blood stem cell transplantation with post-transplantation cyclophosphamide, tacrolimus and mycophenalate mofetil. Biol Blood Marrow Transplant. 2016; 22(6):1037-1042.

17. Maschan MA. Alpha/beta- T lymphocyte depletion: a reliable platform for development of hematopoietic stem cell transplants from haploidentical donors. Russian Journal of Pediatric Hematology and Oncology. 2015; 2(3): 34-38 (In Russian).

18. Zecca M, Strocchio L, Pagliara D, Comoli P, Bertaina A, Giorgiani G, Perotti C, Corbella F, Brescia L, Locatelli F. HLA-haploidentical T-cell-depleted allogeneic hematopoietic stem cell transplantation in children with Fanconi anemia. Biol Blood Marrow Transplant. 2014; 20(4):571-576.

19. Wang Z, Zheng X, Yan H, Li D, Wang H. Good outcome of haploidentical hematopoietic SCT as a salvage therapy in children and adolescents with acquired severe aplastic anemia. Bone Marrow Transplantation 2014; 49:1481-1485.
20. Xiao-jun Huang. Current status of haploidentical stem cell transplantation for leukemia. Journal Hematol Oncol. 2008; $1: 27$.

21. Wang Y, Chang Y-J, Xu L-P, Liu K-Y, Liu D-H, Zhang $\mathrm{X}-\mathrm{H}$, Chen $\mathrm{H}$ et al. Who is the best donor for a related HLA haplotype-mismatched transplant? Blood 2014; 124:843850 .

22. Luznik L, O’Donnell PV, Symons HJ, Chen AR, Leffell MS, Zahurak $M$ et al. HLA-haploidentical bone marrow transplantation for hematologic malignancies using nonmyeloablative conditioning and high-dose, post transplantation cyclophosphamide. Biol Blood Marrow Transplant 2008; 14: 641-650.

\section{Десятилетний опыт применения аллогенной транс- плантации гемопоэтических стволовых клеток от гаплоидентичного донора неманипулированного трансплантата у детей и подростков с острыми лейкозами высокой группы риска}

Олеся В. Паина, Полина В. Кожокарь, Анастасия С. Боровкова, Анастасия С. Фролова, Кирилл А. Екушов, Татьяна А. Быкова, Жемаль 3. Рахманова, Мария А. Галас, Айгуль Г. Хабирова, Инна В. Маркова, Елена В. Семенова, Сергей Н. Бондаренко, Елена В. Бабенко, Татьяна Л. Гиндина, Александр Л. Алянский, Ильдар М. Бархатов, Борис И. Смирнов, Людмила С. Зубаровская, Борис В. Афанасьев

НИИ детской онкологии, гематологии и трансплантологии им. Р. М. Горбачевой; Первый Санкт-Петербургский государственный медицинский университет им. академика И. П. Павлова Министерства здравоохранения России; Санкт-Петербургский государственный электротехнический университет «ЛЭТИ», Санкт-Петербург, Россия

\section{Резюме}

Гаплоидентичная трансплантация (гапло-ТГСК) эффективный метод лечения пациентов с острыми лейкозами высокой группы риска (ОЛ), не имеющих полностью совместимого по генам HLA-системы родственного донора и неродственного донора в Международном регистре. За десятилетний период в НИИ ДОГиТ им. Р. М. Горбачевой выполнено более 150 аллогенных трансплантаций от гаплоидентичного донора, превалирующая часть, как терапия «спасения» больным в первично-резистентном течении ОЛ и/или резистентном течением рецидива ОЛ.
Цель

Оценить эффективность гапло-ТГСК у больных с ОЛ высокой группы риска, выполненной в 1 и 2 ремиссии.

\section{Материалы и методы}

106 больных с ОЛ высокой группы риска, медиана возраста 7 лет (от 0 до 18 лет), ОЛЛ - 63 (59,4\%), ОМЛ 43 (40,6\%), получивших гапло-ТГСК с декабря 2006 года по декабрь 2016 года. В ремиссии заболевания гапло-ТГСК выполнена у 43 больных (40,6\%): в 1й ремиссии - 21 (49\%), во 2 й - 13 больных (30\%), в 3й 9 (21\%). В резистентном течении болезни или реци- 
диве ОЛ - 63 (59,4\%) пациента. МАК «GIAC» 39 человек (36,8\%), МАК на основе Бусульфана $12 \mathrm{Mг} /$ кг и Флюдарабина 150мг/м(2) - 2 (2\%), МАК со сниженной токсичностью на основе Треосульфана 42 г/м ${ }^{2}-$ 6 (5,7\%), РИК на основе Мелфалана $140 \mathrm{Mr} / \mathrm{M}(2)$ у 40 (37,7\%), РИК с использованием Бусульфана 8мг/кг 18 (17\%). Все больные получили профилактику острой реакции «трансплантата против хозяина» (оРТПХ). Серопрофилактика АТГАМ 60мг/кг - 39 (36,8\%), ПТЦф 50мг/кг Д+3, Д+4 - 67 (63,2\%). Базовая ИСТ: такролимус 47 (44,3\%), циклоспорин А в 59 (55,7\%) случаях. Источник трансплантата ГСК праймированный КМ и ПСКК, в комбинации - 27 (25,5\%) и гапло-КМ - 79 (74,5\%). Клеточность трансплантата КМ по CD34+х106/кг от 1 до 9х106/кг (медиана $5,9 \times 10^{6} /$ кг), клеточность КМ+ПСКК от 2,5 до $30,9 \times 10^{6} /$ кг (медиана 5,9х10\%/кг). Статистический анализ: SPSS Statistics v.17. Выживаемость и кумулятивная вероятность анализированы по методу Каплана-Майера. Пациенты, живущие в ремиссии на момент анализа данных, цензурированы 01.01.2018 года. Сравнение OB выполнялось при помощи log-rang теста, сравнительный анализ разности долей - точного теста Fisher. Статистически значимыми считались различия при $\mathrm{p}<0,05$.

\section{Результаты}

Приживление трансплантата после гало-ТГСК зафиксировано у $80(75,7 \%)$ реципиентов. Медиана приживления составила Д+24 (Д+14 - Д+34). Первичное неприживление трансплантата зафиксировано у 26 $(24,5 \%)$ пациентов по причине химиорезистентности и резистентного течения рецидива ОЛ. Медианы восстановления: гранулоциты (>0,5х10\%/л) Д+21 (Д+10 - Д+47), лейкоциты (>1,0 х109/л) Д+20 (Д+10 Д+47), тромбоциты (>20х10\%/л) Д+20 (Д+10 - Д+72), лимфоциты (>30х10\%/л) Д+17 (Д+12 - Д+73). Полный донорский химеризм к 30-му дню определялся у 67 (83,8\%) пациентов, к 60 дню - у 13 (16,2\%). 10-летняя ОВ после гапло - ТГСК - 33,3\%. Выживаемость в 1 и 2 ремиссиях составила 64,7\% против 18,1\% в группе трансплантированных вне ремиссии $(\mathrm{p}=0,01)$. Тип ОЛ не повлиял на ОВ $36,5 \%$ против $27,9 \%$ ОЛЛ и ОМЛ соответственно. Частота развития рецидивов после гапло-ТГСК, выполненной в 1 и 2 ремиссии составила 23,5\%, с медианой наступления Д+88 (Д+30 Д+301). Частота развития оРТПХ II0 - 21 (26,3\%) человек, оРТПХ III0-IV0 - 15 (18,6\%) человек.

\section{Выводы}

Гапло-ТГСК в 1 и 2 ремиссиях ОЛ, позволяет достигнуть 10 -летней ОВ у 64,7\% детей, при этом тип острого лейкоза не влияет на исход гапло-ТГСК. Приемлемая частота развития оРТПX III0-IV0 - 18,6\% позволяет рассматривать гапло-ТГСК, как терапию в 1 и 2 ремиссиях ОЛ высокой группы риска. Основным осложнением гапло-ТГСК является рецидив 23,5\% в ранний посттрансплантационный период до Д+100.

\section{Ключевые слова}

Аллогенная трансплантация гемопоэтических клеток, гаплоидентичная, дети, общая выживаемость, рецидивирование, реакция «трансплантат против хозяина». 